Prepared for the U.S. Department of Energy

under Contract DE-AC05-76RL01830

\title{
Targeted Energy Efficiency Expert Evaluation (E4) Report: Bannister Federal Complex Kansas City, MO
}
J Goddard
R Underhill
N Fernandez
K Gowri

March 2013

Pacific Northwest

NATIONAL LABORATORY

Proudly Operated by Battelle Since 1965 


\section{DISCLAIMER}

This documentation was prepared as an account of work sponsored by an agency of the United States Government. Neither the United States Government nor any agency thereof, nor Battelle Memorial Institute, nor any of their employees, makes any warranty, express or implied, or assumes any legal liability or responsibility for the accuracy, completeness, or usefulness of any information, apparatus, product, or process disclosed, or represents that its use would not infringe privately owned rights. Reference herein to any specific commercial product, process, or service by trade name, trademark, manufacturer, or otherwise does not necessarily constitute or imply its endorsement, recommendation, or favoring by the United States Government or any agency thereof, or Battelle Memorial Institute. The views and opinions of authors expressed herein do not necessarily state or reflect those of the United States Government or any agency thereof.

\section{PACIFIC NORTHWEST NATIONAL LABORATORY \\ operated by \\ BATTELLE \\ for the \\ UNITED STATES DEPARTMENT OF ENERGY \\ under Contract DE-AC05-76RL01830}

Printed in the United States of America
Available to DOE and DOE contractors from the Office of Scientific and Technical Information, P.O. Box 62, Oak Ridge, TN 37831-0062;
ph: (865) 576-8401, fax: (865) 576-5728 email: reports@adonis.osti.gov

\footnotetext{
Available to the public from the National Technical Information Service, U.S. Department of Commerce, 5285 Port Royal Rd., Springfield, VA 22161 ph: (800) 553-6847, fax: (703) 605-6900 email: orders@ntis.fedworld.gov online ordering: http://www.ntis.gov/ordering.htm
} 


\section{Targeted Energy Efficiency Expert Evaluation (E4) Report: Bannister Federal Complex, Kansas City, MO}

JK Goddard

N Fernandez

RM Underhill

K Gowri

March 2013

Prepared for

Federal Energy Management Program U.S. Department of Energy

under Contract DE-AC05-76RL01830

Pacific Northwest National Laboratory

Richland, Washington 99352 


\section{Executive Summary}

Since 2007, PNNL has conducted Energy Efficiency Expert Evaluations (E4) field training and facility assessment in the Heartland Region (GSA Region 6) buildings to identify low-cost/no-cost opportunities that have the potential to reduce building energy use by up to 10 percent. Based on a follow-up study and feedback from operation and maintenance (O\&M) staff, it was recognized that only 50 percent of the recommended measures were implemented and the lack of control systems expertise was often found to be a major challenge in following up on the E4 recommendations. Hence the region undertook a new initiative in 2011 to perform targeted E4 field audits to identify and assist O\&M staff implement control system measures to realize the energy savings.

The Targeted E4 retuning process uses the building automation system (BAS) and the site metering data (ION or other if different) as the central tool in the investigation, monitoring and diagnosis of the operating condition of the building equipment and systems. The Targeted E4 process begins with virtual meetings between the Targeted E4 Team, Regional Energy Engineer, Building Managers/staff and O\&M contractor to review the BAS and key building systems. These meetings identify BAS trends to set up and save in the building BAS system, along with establishing a complete trend logging process. A minimum of 2-3 weeks of trend data is used before the first site visit to be analyzed by the Targeted E4 team before arriving at the facility. Energy Charting and Metrics (ECAM) tool is used to process the data that results in several charts and graphs highlighting building performance along with individual HVAC system performance (air handlers, terminal boxes, chiller plant, hot water plant, etc.).

During the Targeted E4 process, particular emphasis is made to provide training and implementation assistance to O\&M staff. This training includes setting up and use trends and some graphical diagnostic aids pertinent to economizers and chiller performance. The on-site training emphasizes using trend data to evaluate hot/cold calls as well as diagnosis of the operating conditions of a particular piece of equipment and evaluating the actual schedules of equipment versus the actual hours of operations (including scheduled overtime utilities). Overall, the training focuses on optimizing set points, schedules and sequences to save energy without sacrificing the comfort of the occupants of the building. Training also focuses on steering the operators away from using overrides as a normal operating procedure, and to look at the system as a whole to make energy smart adjustments to the BAS. O\&M staff are also trained on how to adjust or reverse any control system changes made during the Targeted E4 process, in the event that the changes do not work as expected. In addition, the Targeted E4 team provided phone and email support to the building staff and O\&M staff during the retuning process.

A dedicated regional energy engineer (Linda Baschnagel) is assigned to coordinate and facilitate all Targeted E4 efforts, provide metered data reports and provide support to site staff with implementation of the recommended measures and on-going monitoring of the building performance. This coordination is found to be critical for the success of the Targeted E4 process.

This report summarizes the targeted E4 measures identified and implemented in the Bannister Federal Complex in Kansas City, MO. A total of 15 energy savings measures were identified and eight of them were fully or partially implemented. Some of the measures included in this report were recommended or implemented at the time of the Targeted E4 site visit, but further analysis shows they may have little to no 
impact. Bannister Complex staff is encouraged to review the proposed action plan and estimated savings in determining the implementation priorities for the remaining measures.

The estimated energy savings of all the identified measures is $3-4$ percent. An analysis of utility billing data since the initial visit (December 2011) shows that the building energy use has decreased by 0.6 percent which represents an increase of 6 percent increase after weather correction. Though there are more vacant spaces in Building 1, there is a 25 percent increase in chilled water use while the electricity consumption decreased by 10 percent. Bannister site staff should continue to monitor the utility bills and determine the cause of this increased chilled water use. Since there are no advanced metering capabilities in this complex, further detailed investigation is recommended by setting trend data collection in the BAS to identify the performance issues if there are any causing the increase in chilled water use. This report includes an action plan for O\&M staff to monitor and improve the effectiveness of the targeted E4 measures identified and implemented. 


\section{Table of Contents}

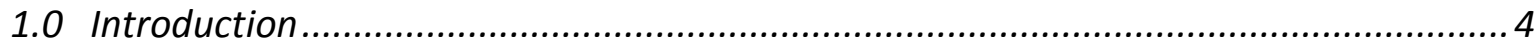

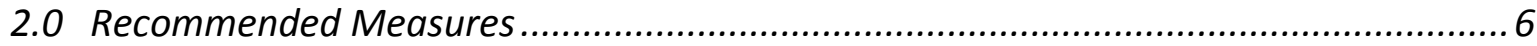

2.1 Measure 1 (Building 1): Add Schedules to AHU's to Shut Down at Night 6

2.2 Measure 2 (Building 1): Reduce Existing AHU Schedules by 1 hour $\quad 7$

2.3 Measure 3 (Building 1): Control Code Changes $\quad 8$

2.3 Measure 3 (Building 1): Control Code Changes 9

2.4 Measure 4 (Building 1): Economizer Control Strategy based -on Dry-bulb Temperature 10

2.5 Measure 5 (Building 2): Static Pressure Reset 11

2.6 Measure 6 (Building 2): Supply Air Temperature Reset 12

2.6 Measure 6 (Building 2): Supply Air Temperature Reset 13

$\begin{array}{ll}2.7 \text { Measure } 7 \text { (Building 2): Add/Adjust AHU Schedule } & 14\end{array}$

2.8 Measure 8 (Building 2): VAV Boxes in Vacant Spaces 15

2.9 Measure 9 (Building 2): Minimum Outdoor Air during Unoccupied Hours 16

2.10 Measure 10 (Building 2): Change Control Code for Return Fans 17

2.11 Measure 11 (Building 2): Scheduling of Restroom Exhaust Fans 18

2.12 Measure 12 (Building 2): Fix Steam Leak 19

2.13 Measure 13 (Building 2): Demand Control Ventilation 20

2.14 Measure 14 (Building 2): Heating Valves Open in Unoccupied Mode 21

2.15 Measure 15 (Building 2): Miscellaneous Observations and Recommendation 22

3.0 Measurement and Verification of Energy Savings ...............................................2 23

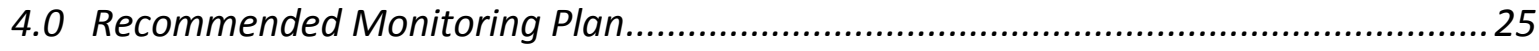






\subsection{Introduction}

As part of a new targeted E4 initiative by the Heartland Region, PNNL staff members conducted an energy efficiency field audit at Bannister Federal Complex in December 2011. During that time, discussions with O\&M staff and review of mechanical, electrical and control systems were performed to identify energy efficiency improvements. PNNL staff worked with site O\&M staff to directly implement many of these recommendations. Some measures were determined to be infeasible, and others required assistance from Johnson Controls (JCI). PNNL followed up with a subsequent visit in February 2012 to modify some of the implemented measures and to implement some of the measures that were not addressed during the December 2011 visit. This report summarizes low-cost/no-cost opportunities identified and building control system changes that were implemented during these two visits. The Bannister Complex consists of six buildings that cover a total of 1.5 million square feet of floor area. This report focuses only on Buildings 1 and 2, which constitute 1.3 million square feet, or 84 percent of the floor area of the complex. Table 1 summarizes the energy saving measures that were identified and the status of implementation. (A detailed discussion on each of these measures is included in the next section.) A preliminary estimate of the potential energy saving for each measure has been calculated as shown in Table 1. Because PNNL has not developed an energy model for the Bannister Complex, the expected savings have been calculated based on reasonable assumptions about each particular measure's efficacy and the fraction of the site that they apply to. In many cases, the measures are complex or based on unknown factors and so savings cannot reasonably be estimated, and these are identified as "Unknown" in Table 1. Estimated savings are meant to convey a conservative estimate of the savings potential.

Table 1. Summary of Energy Efficiency Measures and the Expected Savings

\begin{tabular}{|c|c|c|c|}
\hline No. & Description & $\begin{array}{l}\text { Expected } \\
\text { Savings }\end{array}$ & $\begin{array}{c}\text { Status / } \\
\text { Implementation Notes }\end{array}$ \\
\hline \multicolumn{4}{|c|}{ BUILDING 1} \\
\hline 1 & $\begin{array}{l}\text { Add schedules to Air Handling Unit (AHU) } \\
\text { to shut down at night }\end{array}$ & $0.9 \%+$ & Implemented during February site visit \\
\hline 2 & Reduce existing AHU schedules by 1 hour & $0.9 \%$ & Implemented by site staff following December visit \\
\hline 3 & Control code changes & Unknown & $\begin{array}{l}\text { Partially implemented. Further implementation may require } \\
\text { JCI Support }\end{array}$ \\
\hline 4 & $\begin{array}{l}\text { Economizer control strategy based on dry- } \\
\text { bulb temperature }\end{array}$ & None & Not implemented \\
\hline \multicolumn{4}{|c|}{ BUILDING 2} \\
\hline 5 & Static pressure reset & $0.5 \%$ & $\begin{array}{l}\text { Implemented in December, determined to be working well } \\
\text { during February visit }\end{array}$ \\
\hline 6 & Supply air temperature reset & $0.6 \%$ & Implemented in December \\
\hline 7 & Add/adjust AHU schedules & $0.6 \%+$ & Implemented by site staff following the December visit \\
\hline 8 & VAV boxes in vacant spaces & Unknown & Bannister staff partially implemented this measure. \\
\hline 9 & $\begin{array}{l}\text { Minimum outdoor air during unoccupied } \\
\text { hours }\end{array}$ & $0.1 \%$ & Not implemented yet. May require JCI Support \\
\hline 10 & Change control code for return fans & Unknown & Partially implemented with JCI's assistance in February \\
\hline 11 & Scheduling of Restroom Exhaust Fans & Unknown & Cannot be implemented due to a plumbing vent issue \\
\hline 12 & Fix steam leak & Unknown & $\begin{array}{l}\text { O\&M staff following up on recommendation. Work on- } \\
\text { going as of February } 2012\end{array}$ \\
\hline 13 & Demand control ventilation & Unknown & Recommendation declined for practical reasons \\
\hline 14 & Heating valves open in occupied mode & Unknown & Scheduled to be implemented as of February 2012 \\
\hline 15 & Miscellaneous improvements & None & GSA staff to review \\
\hline
\end{tabular}


Section 2 of the report summarizes each of the recommended measures, implementation strategy and estimated energy savings. Section 3 presents the measurement and verification of energy savings using utility billing data obtained from the GSA energy use summary reports. The verification is done by comparing weather adjusted energy use before and after the targeted E4 measures implementation. A list of recommendations for continued monitoring and future implementation actions are presented in Section 4, followed by general conclusions of the impact of targeted E4 in Section 5. 


\subsection{Recommended Measures}

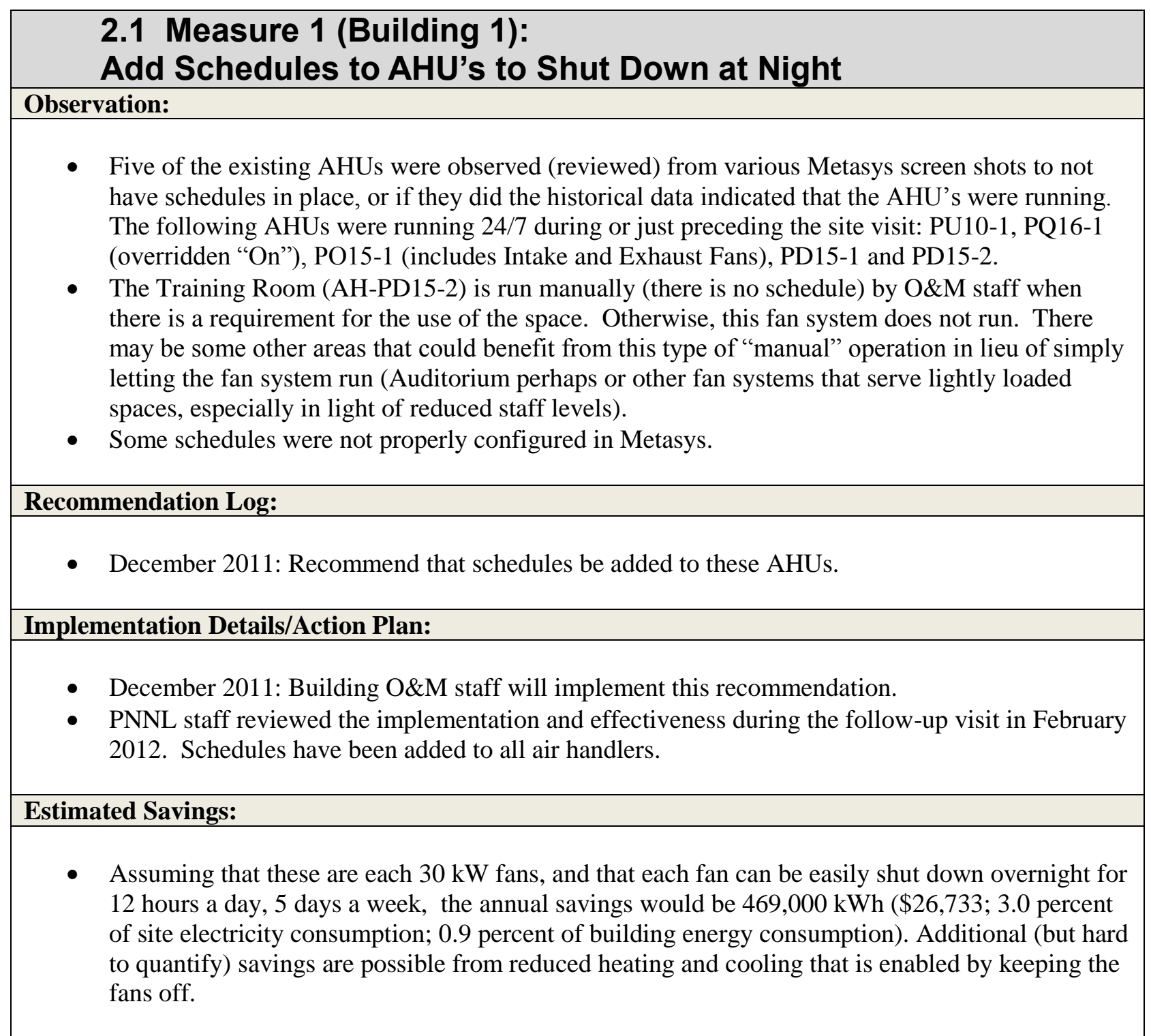




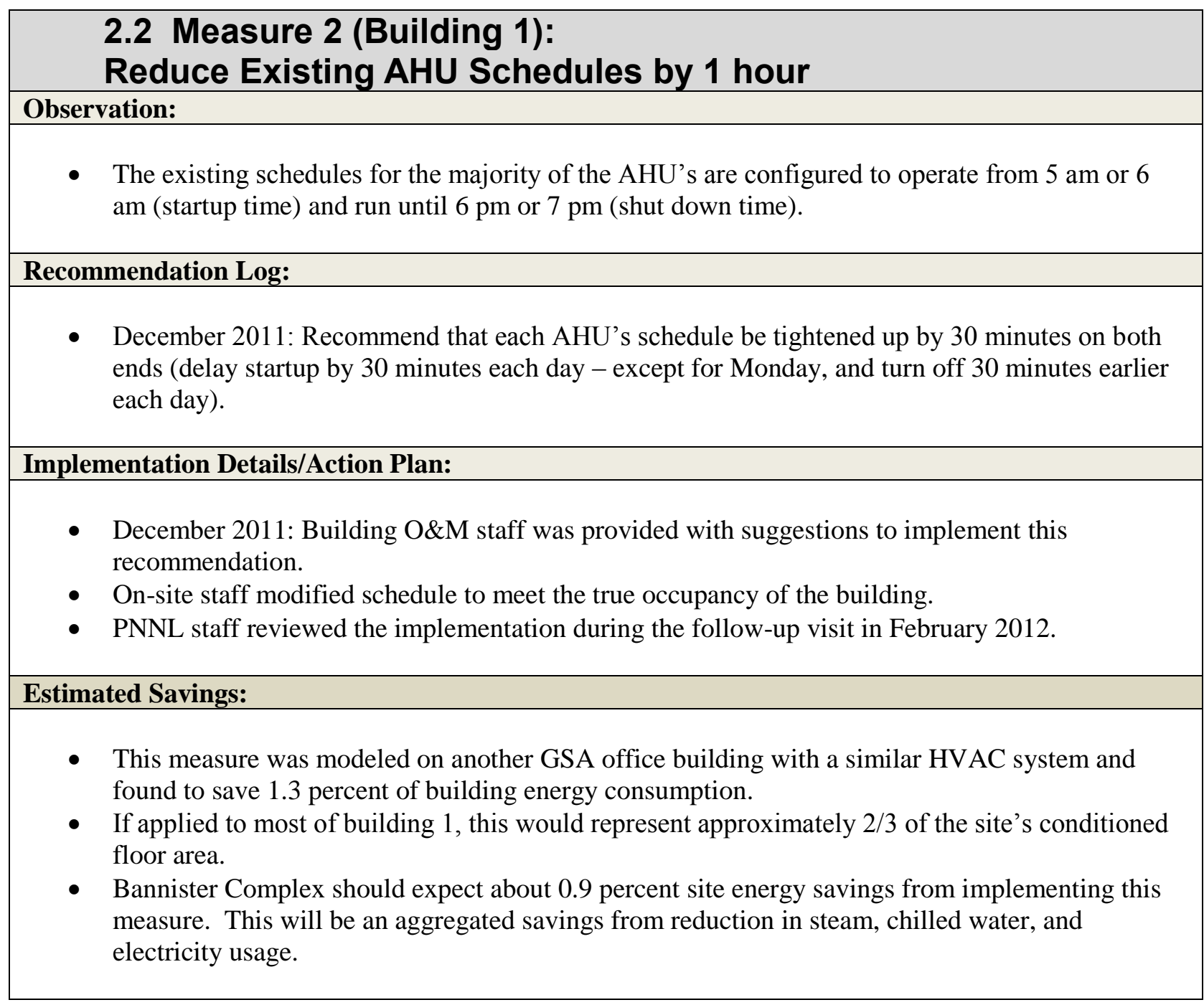




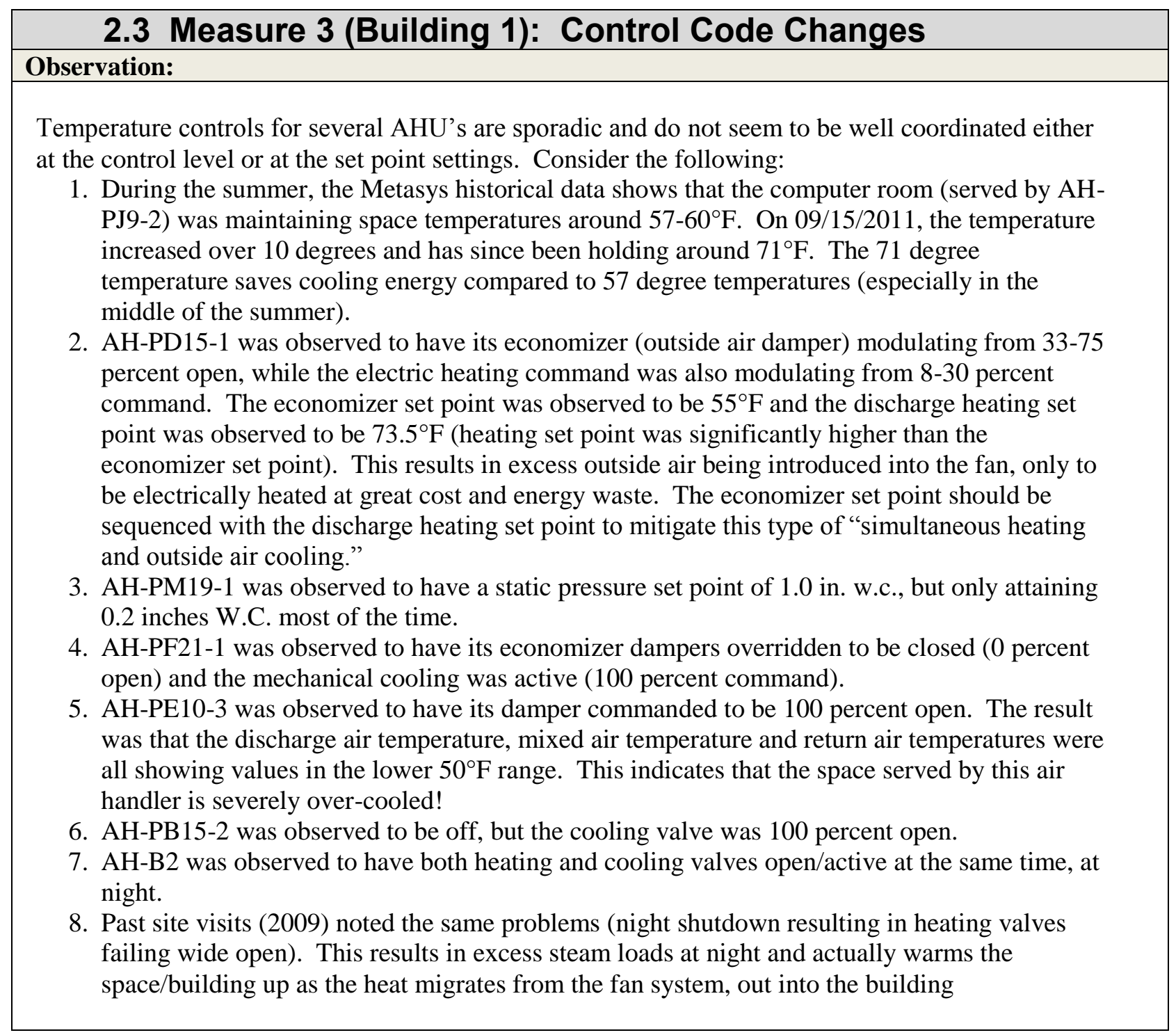




\subsection{Measure 3 (Building 1): Control Code Changes}

Recommendation Log:

December 2011: Recommend that the control code be changed to ensure the following is occurring (this list matches the observations above):

1. Keep computer room temperatures at a reasonable temperature that is not over-cooling the spaces (at great cost). Any temperature that is lower than 65 is probably too cold.

2. Modify control code to ensure that economizer dampers are not modulating beyond the required minimum outside air setting while heating is active. This may be a simple set point change or could be more sophisticated automatic set point adjustment, etc.

3. Fix VFD or inlet vanes and the control signal to them to ensure required static pressures are being maintained. If VFD or inlet vanes are operating correctly, verify that the static pressure sensor is working and calibrated correctly.

4. Periodically (at least once/week) review overrides and determine if they are valid for all HVAC systems. The damper overridden to 0 percent open is causing the need for mechanical cooling, which should not be occurring unless there is a economizer failure (which should be repaired)

5. The control sequence and buried objects (CS objects) should be evaluated to determine why the economizer damper is 100 percent open. If the AHU has a $\mathrm{CO} 2$ sensor, ensure that the sensor has not failed and showing an excessively high $\mathrm{CO} 2$ reading. This can contribute to the controller commanding the economizer dampers to be fully open. Whatever the cause is, it should be determined and resolved to mitigate over-cooling the space.

6. When any air handler system shuts off, the control sequence should close the heating coil control valve, the cooling coil control valves and the outside air dampers. The only time the heating coil control valve should open, is when the outside air temperature is below $35^{\circ} \mathrm{F}$ and the mixed air temperature is below $45^{\circ} \mathrm{F}$ (indicating cold air is migrating into the air handler). Otherwise, keep the steam coil control valves closed.

7. Same comment as \#6.

8. Same comment as \#6.

\section{Implementation Details/Action Plan:}

- December 2011: These recommendations may require the support of the local JCI control service technician to implement or troubleshoot why the observed conditions are as they are. Suggest that GSA work with their O\&M contractor to bring JCI service technician on-site to look into this.

- February 2012: Most of these sub-recommendations have been implemented by the on-site staff and some are on-going.

\section{Estimated Savings:}

- Unknown, difficult to quantify. 


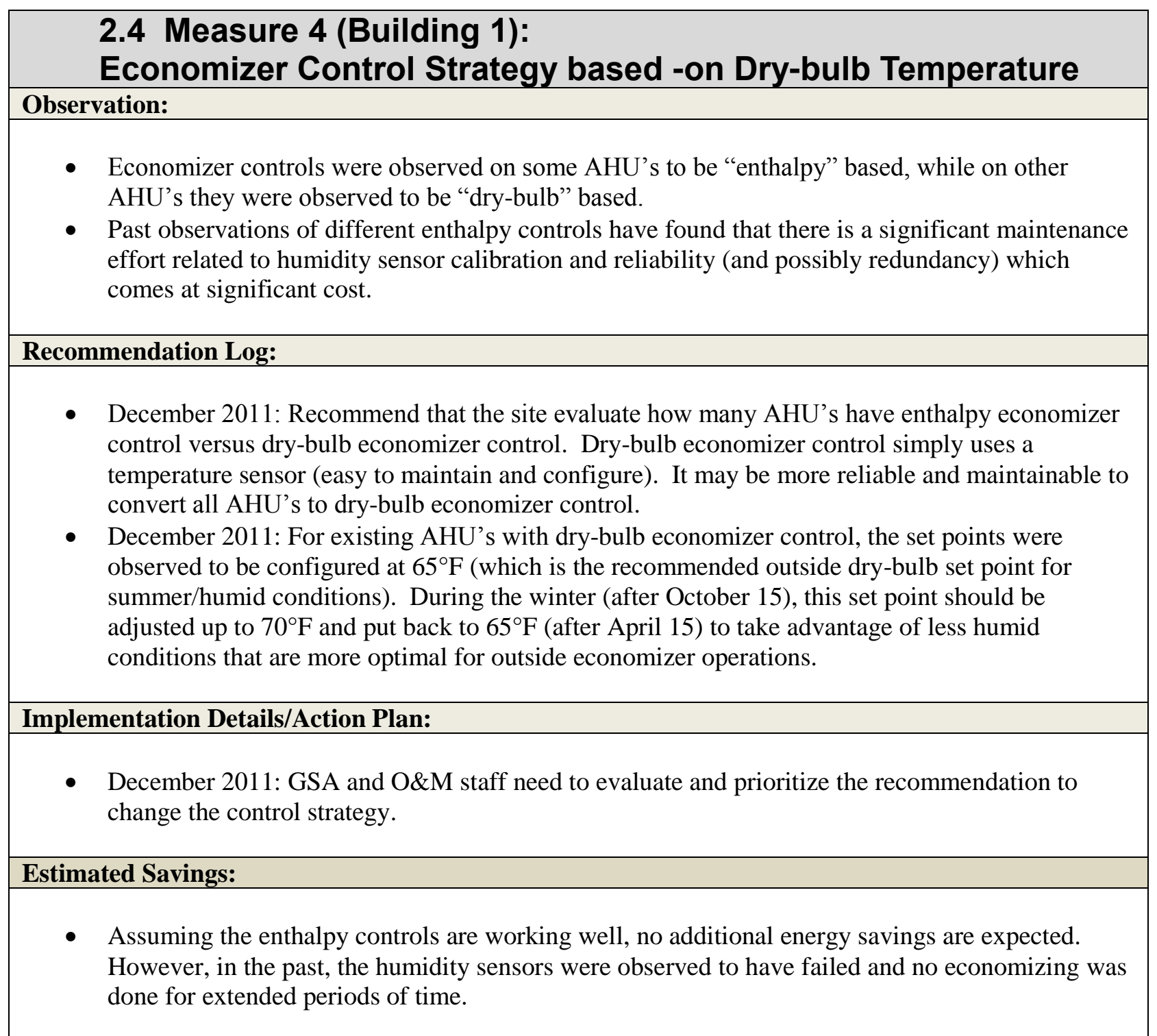




\subsection{Measure 5 (Building 2): Static Pressure Reset \\ Observation: \\ - The existing (5) fan house AHU discharge static pressure set points that serve the different areas of Building 2, were noted as being set at a constant set point value of 2.0 inches W.C. These AHU's serve numerous VAV boxes (mostly new) on 2-3 different floors. \\ - Secondary observation by GSA staff regarding the new VAV boxes. The vendor is "Titus" and the VAV model is "DESV." Per their website, these VAV boxes have no heating coils or cooling coils that require typical high duct static pressure requirements and could very likely work without any issues at static pressures around 1.0" w.c.}

\section{Recommendation Log:}

- December 2011: Recommend that the discharge static pressure set point be reset from 0.75 inches W.C. up to 1.5 inches W.C. Reset should be based upon the average VAV damper position of all the VAV boxes served by the AHU. When the average VAV damper position is 30 percent or lower, the discharge static pressure set point will be at the lower value (operator adjustable currently set at 0.75 inches W.C.) and when the average VAV damper position is 60 percent or greater, the discharge static pressure set point will be at the higher value (operator adjustable currently set at 1.5 inches W.C.).

- February 2012: Static pressure reset is recommended for two additional air handlers: AHU-3B (Mall), AHU-PE10-3 (Atrium), but has not been added yet.

\section{Implementation Details/Action Plan:}

- This was implemented during the week of December 12-16, 2011 for Fan House 1 East, Fan House 1 West, Fan House 2 East, Fan House 2 West and Fan House 3. Five new algorithms and 20 blocks of code (including additional control points) were added to the existing Metasys System Extended Architecture (MSEA) for each Fan House AHU.

- Additional code was written to sum the return fan and supply fan VFD KW readings. Preliminary readings were taken before this was implemented. The readings that were taken after implementation indicate an approximate reduction of 20-30 KW per Fan system.

- This recommendation's performance was reviewed with O\&M staff during PNNL's follow-up visit in February and it was determined to be effective.

- February 2011: Static Pressure Reset has been added to all of the fan houses and Bannister staff are fine tuning the set points to optimize the controlling logic.

\section{Estimated Savings:}

- This measure saves energy by operating the fan at lower power for a given flow rate of air that it delivers. This is true most of the time except during high air flow periods (hot summer days).

- We assume that 75 percent of the time, the fans will be able to operate at a lower power than before, that the average savings is $25 \mathrm{~kW} / \mathrm{fan}$, and that there are five fans affected.

- Savings Calculations:

- $25 \mathrm{kw} /$ fan x 5 fans x 9 months x 12 hours/day x 20 days/month = 270,000 kWh (\$15,300/year).

- This represents 1.7 percent of site electricity consumption or 0.55 percent of site energy consumption. 


\begin{tabular}{|c|}
\hline 2.6 Measure 6 (Building 2): Supply Air Temperature Reset \\
\hline Observation: \\
\hline $\begin{array}{l}\text { - The Fan House A39 discharge temperature set points were observed as being set at a constant set } \\
\text { point value of } 55^{\circ} \mathrm{F} \text { to } 60^{\circ} \mathrm{F} \text {. } \\
\text { The mixed air set points that control the outside air dampers when in economizer mode were also } \\
\text { observed to be incorrectly sequenced with the discharge temperature set points. For instance, Fan } \\
\text { House } 3 \text { was observed to be over-cooling; the mixed air set point was noted as being very low } \\
\left(50-52^{\circ} \mathrm{F}\right) \text { while the discharge temperature set point was observed to be } 60^{\circ} \mathrm{F} \text {. This can result in } \\
\text { more reheat load on the perimeter reheat system that serves the windows to make up for the over- } \\
\text { cooling. The actual discharge air temperature was } 55^{\circ} \mathrm{F} \text {. }\end{array}$ \\
\hline Recommendation Log: \\
\hline $\begin{array}{l}\text { December 2011: Recommend that the supply air temperature set point be reset from } 55^{\circ} \mathrm{F} \text { up to } \\
65^{\circ} \mathrm{F} \text {. Reset should be based upon the return air temperature of the respective AHU. When the } \\
\text { return air temperature is } 71^{\circ} \mathrm{F} \text { or lower, the supply air temperature set point will be at the higher } \\
\text { value (operator -adjustable - currently set at } 65^{\circ} \mathrm{F} \text { ) and when the return air temperature is } 75^{\circ} \mathrm{F} \text { or } \\
\text { greater, the set point will be at the lower value (operator adjustable - currently set at } 55^{\circ} \mathrm{F} \text { ). } \\
\text { December 2011: Recommend that the mixed air set point be automatically synchronized with the } \\
\text { supply air temperature set point (it should run no more than } 3^{\circ} \mathrm{F} \text { below the supply temperature set } \\
\text { point, to account for heat pickup from the supply fan). } \\
\text { - February 2011: Two additional air handlers have been added to this recommendation: AHU-3B } \\
\text { (Mall), AHU-PE10-3 (Atrium). }\end{array}$ \\
\hline Implementation Details/Action Plan: \\
\hline $\begin{array}{l}\text { This was implemented during the week of Dec. 12-16, } 2011 \text { for Fan House } 1 \text { East, Fan House } 1 \\
\text { West, Fan House } 2 \text { East, Fan House } 2 \text { West and Fan House } 3 \text {. Five new algorithms and } 20 \text { blocks } \\
\text { of code (including additional control points) were added to the existing MSEA for each Fan } \\
\text { House AHU. } \\
\text { This recommendation's performance was reviewed with O\&M staff during PNNL's follow-up } \\
\text { visit in February and has been added to all of the fan houses. Staff are fine tuning the set points. }\end{array}$ \\
\hline
\end{tabular}




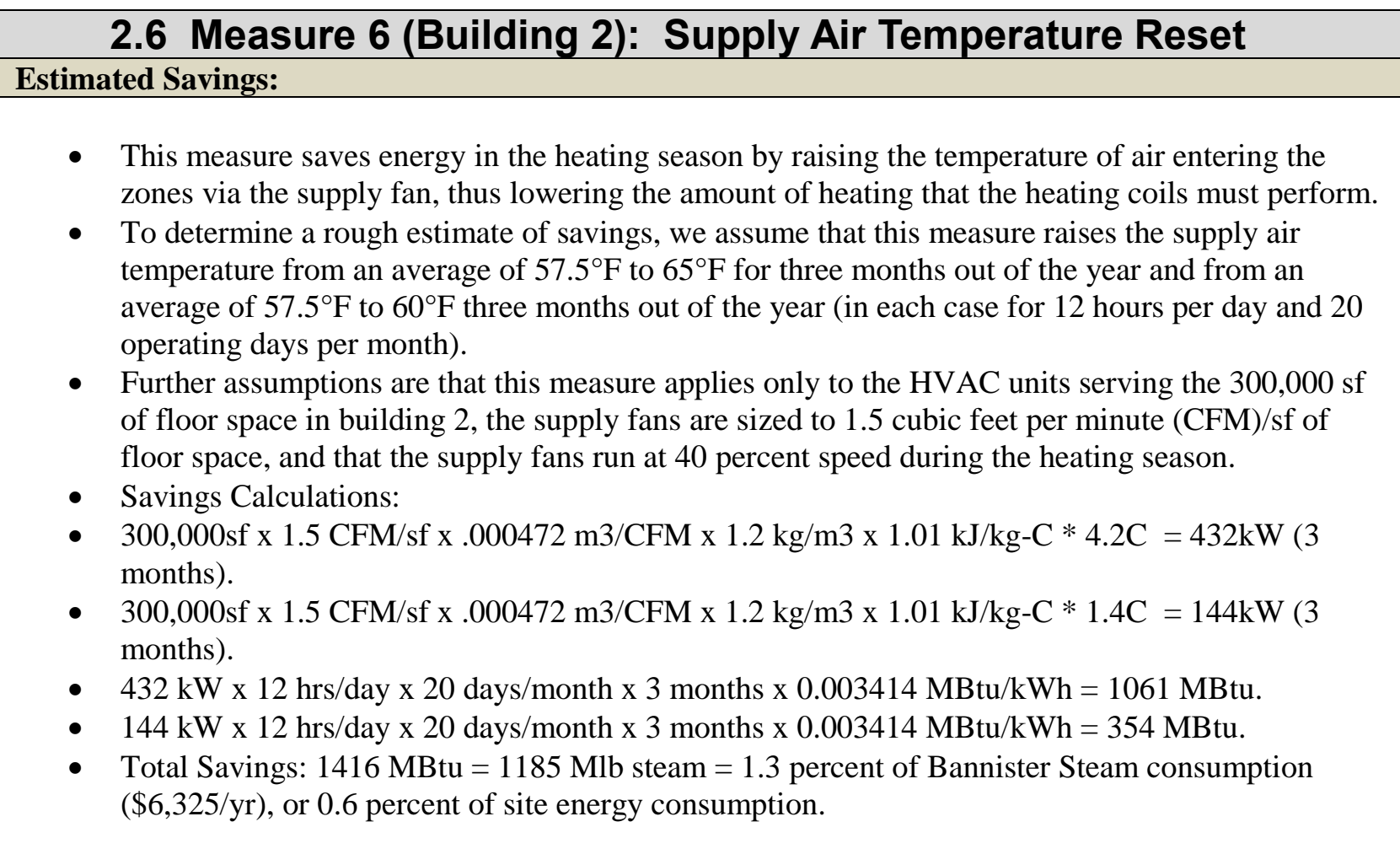




\subsection{Measure 7 (Building 2): Add/Adjust AHU Schedule \\ Observation:}

- Two of the existing Fan House AHU's were observed (reviewed) from various Metasys screen shots, to not have schedules in place. The following AHUs were running 24/7 during or just preceding the site visit: Fan House 2 West and Fan House 2 East. This was discussed with O\&M staff while on-site and determined to be related to construction activities.

- Fan House 1 East has a schedule that starts that AHU fan system at 4 AM every weekday. The other Fan House AHU's (Fan House 1 West and Fan House 3) have 5 am start schedules. All of the stop schedules are configured to be at 6:00 pm (except for Fan House 1 East - 5:30 pm).

\section{Recommendation Log:}

- December 2011: Recommend that schedules be added to the Fan House 2 AHU's as soon as possible.

- December 2011: Recommend that the schedules for the other Fan Houses be tightened up and synchronized with each other so they are within 15 minutes of each other (recommend starting later, rather than earlier) and also pushed toward 5:30 am, not 4:00 am. Also recommend that the stop times be pushed toward earlier $(5: 30 \mathrm{pm})$ times, similar to Fan House 1 East.

Implementation Details/Action Plan:

- Building O\&M staff was provided with details to implement this recommendation.

- PNNL staff reviewed the implementation during the follow-up visit in February 2012.

- Schedules have been added to all air handlers. This measure was completed by on-site staff.

\section{Estimated Savings:}

- The savings estimates is based on the assumption that each of these fans consumes (on average) $40 \mathrm{~kW}$ when running after the static pressure reset.

- Savings from Fan House 2 West and Fan House 2 East, assuming they can be shut off for 12 hours a day, 5 days a week is $249,600 \mathrm{kWh}$, plus an unknown amount of heating and cooling savings.

- Savings from the remaining three fans by shortening their morning operation (assuming each starts instead at 5:30 a.m. is $26,000 \mathrm{~kW}$.

- Total savings is conservatively estimated to be $275,600 \mathrm{kWh} / \mathrm{yr}$. (\$15,665, 1.8 percent of site electricity consumption, or 0.6 percent of site energy consumption). Some additional savings in chilled water and steam are also likely. 


\begin{tabular}{|l|}
\hline 2.8 Measure 8 (Building 2): VAV Boxes in Vacant Spaces \\
\hline Observation: \\
$\begin{array}{l}\text { - } \\
\text { Several areas are now vacant, either due to construction or staff changes. This allows several } \\
\text { areas the opportunity to save fan energy and reduce reheat energy by using the VAV box local } \\
\text { thermostat capability. }\end{array}$ \\
Recommendation Log: \\
- $\begin{array}{l}\text { December 2011: Set the local thermostat set point adjustment dial as high as it will adjust to (do } \\
\text { not implement this on thermostats serving VAV boxes with reheat or on thermostats serving air } \\
\text { handlers with heating coils where the thermostat is used directly by the air handler). By setting } \\
\text { the VAV box to a higher set point, the controls will reduce the air flow, resulting in less load on } \\
\text { the supply fan VFD. }\end{array}$ \\
- $\begin{array}{l}\text { Building O\&M staff implemented this recommendation. } \\
\text { PNNL staff reviewed the implementation during the follow-up visit in February } 2012 .\end{array}$ \\
Many areas have been turned off along with some of the air handlers serving these areas. \\
\hline Estimated Savings: \\
\hline
\end{tabular}




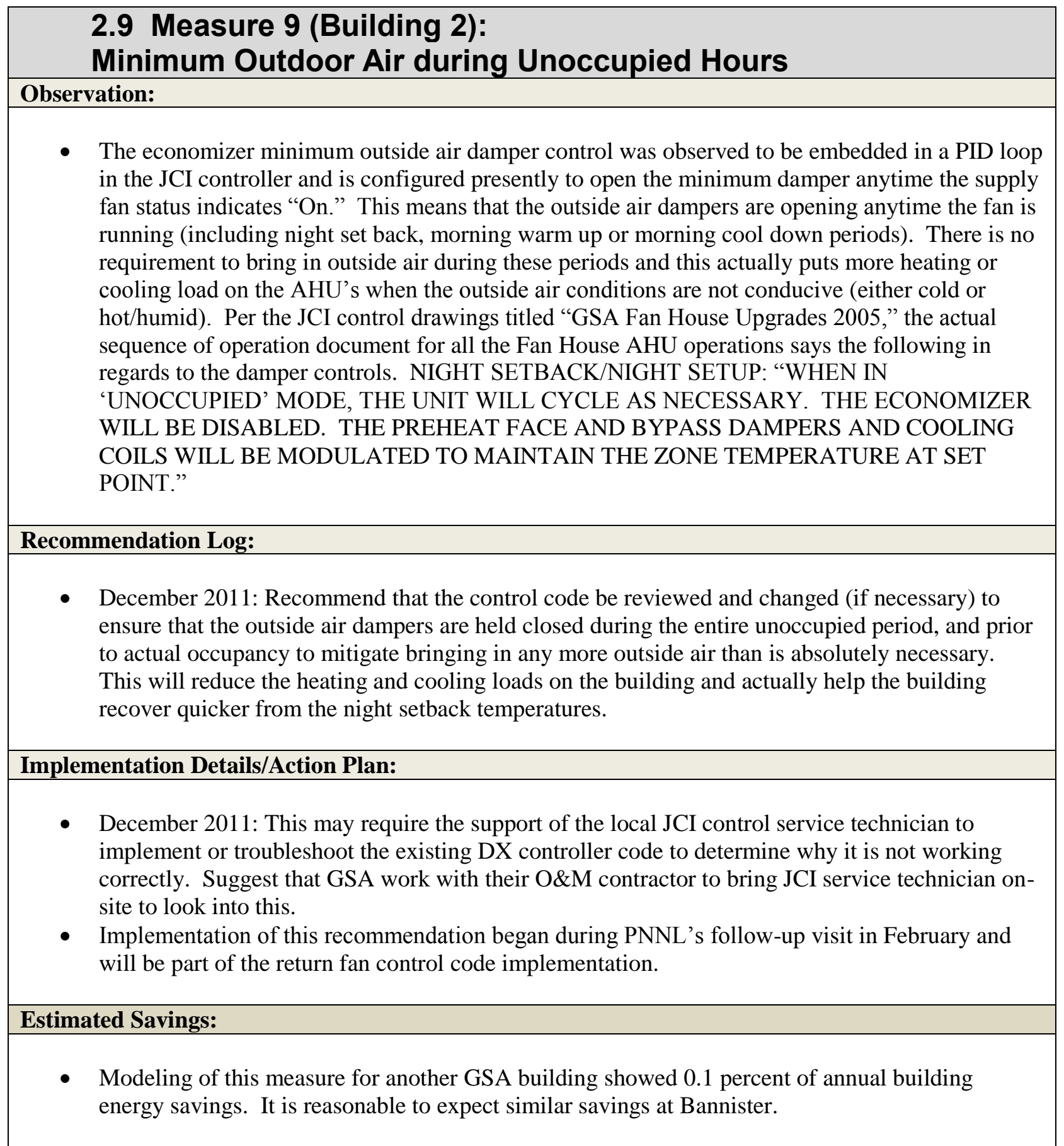




\subsection{Measure 10 (Building 2): Change Control Code for Return Fans}

Observation:

- The Fan House AHU's are supposed to be configured to maintain a differential volume offset such that air flow stations are used to measure the air flow being supplied to the space. The supplied air flow is compared to the air being returned from the space. The ability to set a volume difference (usually to allow for maintaining the building pressure slightly positive and to account for miscellaneous exhaust fans and leaks in the building) is supposed to result in the return fan being operated (via VFD speed controls) to match the volumetric set point difference as measured by the air flow stations. However, upon observation, only one fan house appears to be working correctly. Otherwise, all the other fan house AHU systems were observed to have their return fans operating at a speed that was resulting in significantly higher return cubic feet /minute rates than needed and in many cases significantly more air was being returned than was being supplied. This also can be seen in the calculated outdoor air factions and will impact the air handler's ability to use outside air for free cooling during moderate weather. The control sequence document states that return fan speed controls will be overridden in the control code if the space static pressure is outside certain boundaries. Observations of the building static pressure readings did not appear to be an issue. Observations of several return fan power readings were indicating return fans consuming as much (or more) power than the supply fans. This should not be occurring as return fans do not have as much inherent load to overcome as compared to supply fans.

\section{Recommendation Log:}

- December 2011: Recommend that the control code be reviewed and changed (if necessary) to ensure that the return fans are operating correctly to maintain the correct CFM volume differentials, or the control code should be changed to operate from some other parameter (perhaps building static pressure only or perhaps power differential).

\section{Implementation Details/Action Plan:}

- December 2011: This may require the support of the local JCI control service technician to implement or troubleshoot the existing DX controller code to determine why it is not working correctly. Suggest that GSA work with their O\&M contractor to bring JCI service technician onsite to look into this.

- February 2012: Control code was changed on one fan and tested with the assistance of JCI during PNNL's follow-up visit. The recommendation was tested on one unit and found to work correctly. GSA to schedule JCI back on-site to further implement the code changes on the rest on the air handlers in the building.

\section{Estimated Savings:}

- Unknown. 


\subsection{Measure 11 (Building 2): Scheduling of Restroom Exhaust}

Fans

Observation:

- The exhaust fans that serve different restrooms were observed to be running at night and on weekends (24/7).

- O\&M staff indicated that this may be due to exhaust fan control being bypassed either on Metasys or at the starter/control relay in the Penthouse or other areas. This may be due to smells (not specified as to what that meant). If this is due to sewer fumes, this may indicate a problem with the building's plumbing (traps) not being properly primed, etc.

\section{Recommendation Log:}

- December 2011: Recommend that consideration be given to adding schedules that run the bathroom exhaust fans during the night and weekend periods, but are configured to operate the exhaust fans for 30 minutes each hour (30 minutes on, 30 minutes off). This effectively will reduce the runtime by 50 percent and also reduce outside infiltration rates by similar percentage.

\section{Implementation Details/Action Plan:}

- February 2012: This recommendation was discussed with the O\&M staff during PNNL's followup visit and determined that it cannot be implemented due to a plumbing vent issue in the building.

\section{Estimated Savings:}

- Not estimated. 


\begin{tabular}{|l|}
\hline 2.12 Measure 12 (Building 2): Fix Steam Leak \\
\hline Observation: \\
\hline A small steam leak was observed on Fan House 3 Air Handling Heating coil. Perhaps this is the \\
reason for the Mixed Air Set Point on Fan House 3 being set so low (52 ${ }^{\circ}$ F). If true, using cold \\
outside air to remove excess heat from a leaking steam coil is not energy smart and also means \\
that more mechanical cooling is required to do the same when outside air temperatures are above \\
50-55 ${ }^{\circ}$ F.
\end{tabular}




\begin{tabular}{|l|}
\hline 2.13 Measure 13 (Building 2): Demand Control Ventilation \\
\hline Observation: \\
$\begin{array}{l}\text { All the Fan House AHU's have CO2 sensors and minimum outside air dampers. As already } \\
\text { noted, the minimum outside air dampers open during unoccupied periods when the sequence of } \\
\text { operation document states that they should be closed. To further this discussion, the observation } \\
\text { of CO2 sensors in the return air of each fan system provides the ability to limit the introduction of } \\
\text { outside air, even during occupied periods. }\end{array}$ \\
- $\begin{array}{l}\text { December 2011: Recommend that the current control code be evaluated for inclusion of Demand } \\
\text { Control Ventilation (DCV) by using the existing CO2 sensors. Typical control keeps the } \\
\text { minimum outside air dampers closed or at some very small opening (less than 5 percent) unless } \\
\text { the CO2 reading starts to rise above some minimum threshold value (800 PPM is often a target } \\
\text { value). If the building has a lot of infiltration or leaks (which is likely, given the age and manner } \\
\text { in which the exhaust fans are controlled), than the requirement to introduce additional outside air } \\
\text { at the fans is reduced. The other reason to consider this is the fact that the number of staff in the } \\
\text { building has been reduced, so the amount of fresh air should also have reduced. }\end{array}$ \\
- $\begin{array}{l}\text { Not calculated due to lack of necessary data. } \\
\text { February 2012: This recommendation was discussed with O\&M staff during PNNL's follow-up } \\
\text { trip, and it was decided that it is not going to be implemented since the minimum air dampers are } \\
\text { used for makeup air to the exhaust fans in the building. }\end{array}$ \\
\hline Estimated Savings: \\
\hline
\end{tabular}




\begin{tabular}{|l|}
\hline 2.14 Measure 14 (Building 2): \\
Heating Valves Open in Unoccupied Mode \\
\hline Observation: \\
- $\begin{array}{l}\text { Observation \#3 above in Building 1, also applies to Building } 2 \text { (night shutdown of air handlers } \\
\text { with steam heating coil failing wide open when outdoor air temperature is less than } 45^{\circ} \mathrm{F} \text { ). The } \\
\text { unoccupied control does not differentiate on this and maintains the preheat coil in an "active" } \\
\text { mode to try and maintain the space temperature, which is difficult if the fan is not operating. }\end{array}$ \\
- $\begin{array}{l}\text { December } 2011: \text { When any Fan House air handler system shuts off, the control sequence should } \\
\text { close the heating coil control valve, the cooling coil control valves, and the outside air dampers. } \\
\text { The only time the heating coil control valve should open, is when the outside air temperature is } \\
\text { below } 35^{\circ} \mathrm{F} \text { and the mixed air temperature is below } 45^{\circ} \mathrm{F} \text { (indicating cold air is migrating into the } \\
\text { air handler). Otherwise, the steam coil control valves should be closed. }\end{array}$ \\
- $\begin{array}{l}\text { This recommendation will be fixed at the time of the return fan code changes. It requires some } \\
\text { modification to the code to control valve from the preheat sensor and not from the mixed air } \\
\text { temperature sensor. }\end{array}$ \\
\hline $\begin{array}{l}\text { Unknown, further data collection is needed to calculate savings. } \\
\text { Estimated Savings: }\end{array}$ \\
\hline
\end{tabular}




\subsection{Measure 15 (Building 2):}

\section{Miscellaneous Observations and Recommendation}

Observations and Recommendations:

- There are several minor improvement opportunities that are not "control" improvements, but simply monitoring and diagnostic improvements. This includes using the existing Metasys network to calculate total CFM airflow per AHU (sum the individual VAV box CFM readings) and cooling coil tonnage (delta T x CFM x 1.08/12000). Some of these were implemented during PNNL's follow-up visit in February, however, this is not completed for all systems and O\&M staff are expected to follow-up on this recommendation.

- The individual AHU supply/return fan KW values can also be summed for a total fan KW reading. This was implemented during PNNL's follow-up visit in February and is currently being trended for all fans.

- Several Metasys controllers were observed to be "Offline" and should be fixed or diagnose the problem that is keeping them offline (control power loss, communication problem, etc.). This includes the following controllers - V2W1-13, V31-12, V31-15, V1EB-3, AHP015-1, AHPF21 (Zones 1-26, Mall Warehouse) and FTS Feeder Root. Many of these problems were fixed during PNNL's follow-up visit in February. Many of these systems were in areas that are no longer occupied and systems have been shut down.

- The Mall Warehouse Temperature Sensor (Post T-17.5) was observed to be unreliable and should be fixed or replaced. However, this sensor does not exist in Metasys and is not an issue to be addressed for building control. 


\subsection{Measurement and Verification of Energy Savings}

Figure 1 shows a history of energy consumption at Bannister, using energy use intensity (EUI) as the metric for comparison. The chart shows the actual energy use intensity in blue, as well as the weathercorrected EUI in red. Since FY08, there has been a sharp reduction in energy consumption (22.3 percent in absolute terms, and 24.5 percent after correcting for weather). Toward the end of FY11, significant vacancies took place at Bannister. These vacancies affected the last three months of FY11, and from October-December 2011 they were responsible for 2.2 percent of the overall 9.0 percent savings compared to FY11. FY12 is the first full year after these vacancies occurred, and continued reductions in energy consumption were expected as a result. On top of reduced energy use due to vacancies, PNNL estimated 3-4 percent additional total building energy savings from the implemented Targeted E4 measures. The vacancies and energy measures, unfortunately, did not result in a complex-wide reduction in utility-metered energy consumption in FY12. Based on differences in weather alone, energy consumption should have dropped 6 percent (estimated) from FY11 to FY12, but instead it dropped only 0.6 percent. Thus, there are unknown factors that have been responsible for negating the otherwise positive impacts of vacancies, energy conservation measures and more favorable weather in FY12.

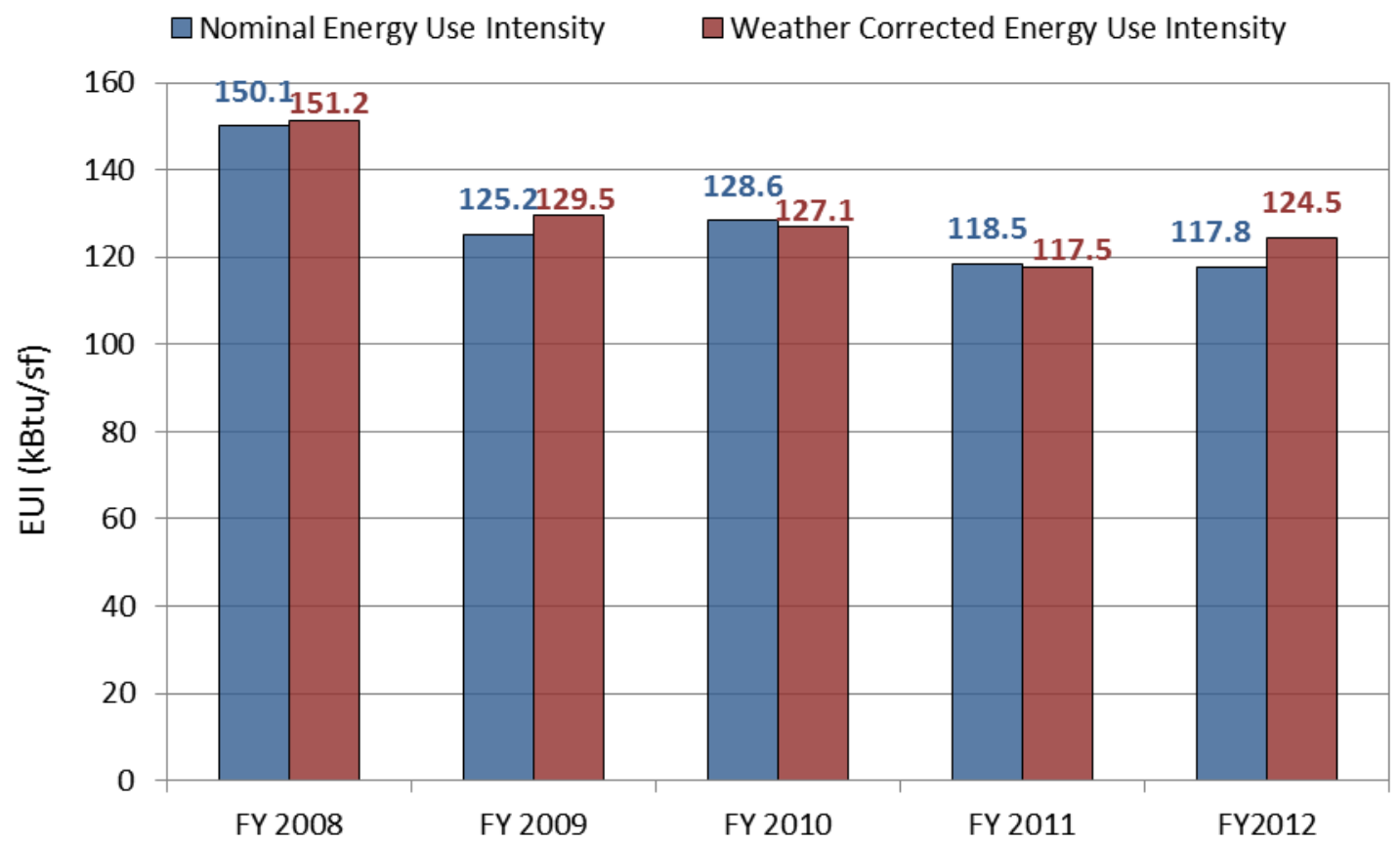

Figure 1. EUI History and Projections for Bannister Complex

Bannister Complex does not have advanced metering or sub-metered data for detailed analysis and verification of energy savings due to Targeted E4 implementations. Hence PNNL analyzed utility billing data as reported by the GSA EUAS system. A rolling twelve month comparison of energy use for periods before and after Targeted E4 is done to assess the impact. Monthly energy use data from the EUAS system for Bannister is presented in Figure 2 to compare monthly energy performance in FY12 to FY11for both the actual and weather-corrected energy consumption. 


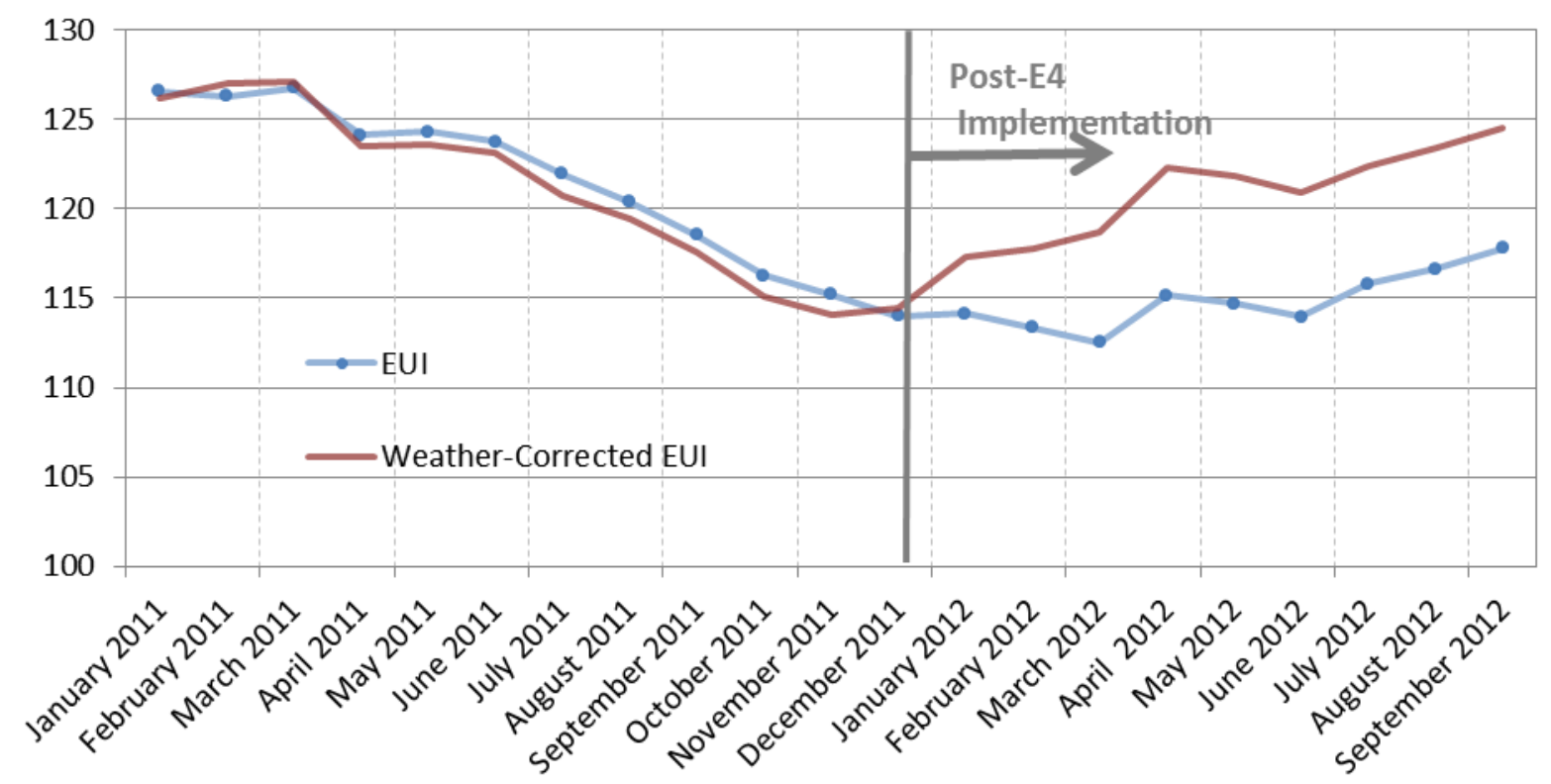

Figure 2. EUAS (Utility Bill) Analysis- Rolling 12-month EUI since January 2011

Figure 2 shows that rather than an energy savings being evident from utility billing data, the site appears to have increased its energy consumption significantly. Energy consumption trends, especially in steam and chilled water, metered at the nearby DOE facility have been unreliable for the last several years, and this year was no exception. It was expected that even without the Targeted E4 improvements, the energy consumption would continue to decline in FY2012 as the effects of recent office vacancies from July 2011 manifested in each month of FY2012 up to July. This was not the case. Steam consumption has increased 8.5 percent relative to FY2011 since the Targeted-E4 December visit (28.4 percent weathercorrected), and chilled water has increased 22.9 percent relative to FY2011 (1.1 percent weathercorrected). However, electricity use decreased by 10.9 percent (13.6 percent weather-corrected). But electricity, accounts for only 25 percent of Bannister's site energy consumption. The implemented Targeted-E4 measures were expected to result in a modest 3-4 percent site energy savings. The much wilder swings in the three utility meters indicate that the "signal-to-noise" ratio is far too low to make any useful conclusions about Targeted E4 effectiveness. The Continuous Monitoring Plan may serve as a better tool to gauge the effectiveness of the measures, even if their energy savings cannot be verified quantitatively. 


\subsection{Recommended Monitoring Plan}

This section provides recommendations for continued monitoring and implementation of several of the measures summarized in Section 2 and implemented as part of the Targeted E4 actions taken during FY12.

\section{Measures 1-4 (Building 1): Consolidated monitoring plan}

Monitoring Timeframe: Once Annually

Building 1 has limited BAS digital control and monitoring is limited to high-level verification and physical checks of systems.

- Verify that schedules keeping PU10-1, PQ16-1, PO15-1, PD15-1 and PD15-2 off at night.

- Generate updated lists of tenant scheduled occupancy and new vacant spaces. Determine if any air handlers are being run longer than the occupancy currently requires. If so, tighten air handler schedules.

- Verify that computer room thermostat set points remain above $65^{\circ} \mathrm{F}$.

- Verify that economizing (mixed air) set points building-wide are equal to discharge air temperature set points.

\section{Measure 5 (Building 2): Static Pressure Reset}

Monitoring Timeframe: 1 day in spring 2013

Times of moderate weather in the spring should provide a good time to test the effectiveness of static pressure reset at Bannister. Zone airflow demands should be low, and static pressure set points are expected to be at or close to minimum programmed levels.

- Make note of current static pressure minimum and maximum set points in Metasys. Are minimum static pressure set points still at 0.75 " w.c. and maximum set points still at 1.5 " w.c.? If not, why have they changed?

- Trend the static pressure set point for 2-3 air handlers over the course of a typical business day (24 hours). Does the static pressure set point stay near the minimum set point or modulate between the minimum and maximum set point (as desired)?

- If the static pressure set point remains stuck at the maximum set point, can the problem be traced? This should only happen if most of the zone dampers are nearly fully open. If this is not the case, is the static pressure reset algorithm enabled?

- Verifying Savings: Trend supply fan power consumption for 24 hours, then set all minimum and maximum static pressure set points to 2.0" w.c. (previous levels) and trend power consumption for another 24 hours. Export to a spreadsheet and calculate the time-averaged power consumption for all fans in day 1 and day 2. Sum the average consumption across all fans for day 1 and day 2. What fraction of fan energy consumption is the static pressure reset saving? $100 \% x$ [1- (day1 total/ day2 total)]

We expect around 40 percent in the spring/fall and 15-25 percent in the summer/winter. Remember to reset the minimum and maximum static pressure set points back to 0.75 " w.c. and 1.50 " w.c. , respectively after this exercise.

- Enabling Further Savings: Are all of the static pressure set points near their minimum values in the spring? Experiment with lowering the minimum static pressure set points to 0.4 or 0.5 " w.c. 


\section{Measure 6 (Building 2): Supply Air Temperature Reset}

Monitoring Timeframe: 1 day in winter 2012-2013

In the winter, supply air temperatures should be close to their maximum values.

- Make note of current maximum and minimum supply air temperature set points. Are they all set to $65^{\circ}$ and $55^{\circ} \mathrm{F}$, respectively?

- Trend the supply air temperature set point for 2-3 air handlers over the course of a typical business day ( 24 hours). Does the supply air temperature for each air handler stay near $65^{\circ} \mathrm{F}$. If not, try to determine why:

$\circ$ What is the return air temperature for a given air handler? Compare to the zone temperatures in the air handler's network.

- Is the return air temperature a good approximation of the average zone temperature?

$\circ$ If the return air temperature seems significantly higher than the average zone temperature, increase the low-limit return air temperature in the supply air temperature reset algorithm.

- Enabling Further Savings: Are all of the zone temperatures comfortable or cool?

- Raise the low-limit return air temperature in the supply air temperature reset algorithm 1 degree each hour until one or two zones border on becoming too warm $\left(75-77^{\circ} \mathrm{F}\right)$

$\circ$ Raise the high-limit supply air temperature to $70^{\circ} \mathrm{F}$

\section{Measure 7 (Building 2): Add/Adjust AHU Schedules}

Monitoring Timeframe: One Week during mild weather conditions

- Verify that schedules keeping Fan House 2 West and Fan House 2 East off at night remain in place.

- Trend the fan VFD and several zone temperatures for these two AHUs for one week. Does the fan clearly shut off at night? Does the fan only come back on in order to satisfy zone temperatures that are below nighttime setback set points?

\section{Measure 8 (Building 2): VAV Boxes in Vacant Spaces}

Monitoring Timeframe: Once in Winter 2012-2013

- Verify that all VAV boxes without reheat serving vacant spaces have their thermostats set as high as possible.

- If possible on Metasys, set thermostat set points for vacant zones to constant $55^{\circ} \mathrm{F}$ heating set point at $85^{\circ} \mathrm{F}$ cooling set point.

\section{Measure 15 (Building 2): Miscellaneous Observations and Recommendations}

- Check the temperature differential across the steam heating coil on Fan House 3 to verify that the steam leak has been fixed.

- Verify that the mixed air set point for Fan House 3 has been set higher (was $52^{\circ} \mathrm{F}$ ).

- Trend preheat coil control valve command and corresponding fan VFD for one week in the winter and ensure that the preheat coil control valves remain closed whenever the fan VFD is off. 


\subsection{Conclusions}

Bannister Complex is one of the most challenging buildings in Region 6 to take advantage of Targeted E4 effort due to the age of the facility and limited BAS capabilities. However, PNNL identified opportunities for saving 3-4 percent annually by adjusting schedules, and by implementing temperature/pressure resets on various air handlers. In total, there are 15 energy saving opportunities identified and several of them were already implemented.

During FY12, Bannister Complex actual energy use decreased marginally by 0.6 percent compared to FY11. Recent monthly utility bill analysis indicates a trend reversal of increase in overall energy use. Though overall electricity use has decreased by almost 10 percent, the chilled water/tempered water use has increased by 22 percent. This situation requires O\&M staff to investigate the effectiveness of individual measures and review the impact of any recent occupancy changes or operational changes that could contribute to the increase in chilled water/tempered water use.

In order to realize additional savings and further benefit from the recommended and already implemented measures, PNNL has provided an action plan that requires commitment on the part of the building manager and O\&M contractor for continued monitoring and adjustments to the control system. It is important to highlight the need for dedicated regional staff to facilitate and coordinate the implementation, and monitor the effectiveness of Targeted E4 measures. 